\title{
Nasjonale retningslinjer for forebygging av selvmord i psykisk helsevern. Tilpasninger til målgruppen: barn/unge i spesialisthelsetjenesten
}

\author{
Ved Kristin Østlie, Nils Petter Reinholdt og Johan Lindmark
}

\section{ABSTRACT}

Nasjonale retningslinjer for forebygging av selvmord i psykisk helsevern ble publisert i 2008, og i tiden etterpå har det vært mye oppmerksomhet knyttet til implementering av disse i helseforetakene. RVTS Øst og Sør har gjennom oppdragsbrev fra Helsedirektoratet fått i oppgave å bistå sykehusene i dette arbeidet.

Gjennom vårt arbeid ute i foretakene/sykehusene har det blitt fremhevet et behov for operasjonalisering av retningslinjene med tanke på en bedre tilpasning til målgruppen barn og unge i spesialisthelsetjenesten.

Med bakgrunn i dette tok RVTS Øst initiativ til etablering av et faglig nettverk der alle foretakene/ sykehusene ble invitert til å delta. Deltakerne har til sammen bred og solid kompetanse forskningsmessig og klinisk, og har gjennom sin forankring representert både døgnbehandling og det polikliniske perspektiv.

Nettverket har møttes tre ganger i løpet av 2011 i tillegg til at deler av arbeidet har foregått lokalt, og i undergrupper. Sentrale tema i arbeidet har vært: alderstilpasning, nettverk, kartlegging, vurdering og dokumentasjon

Fra RVTS og arbeidsgruppen foreslås det at man ved de enkelte helseforetak anvender dette dokumentet som grunnlag for egne prosedyrer/retningslinjer. Dokumentet har til hensikt å øke kvaliteten i det selvmordsforebyggende arbeidet for barn og ungdom i spesialisthelsetjenesten

Norwegian guidelines for Suicide prevention in psychiatric health care were published in 2008 , since then there has been much focus on the implementation process of these in the Norwegian hospitals. RTVS (Regional centre for Trauma and Sucide Prevention) East and South have via directive letters from the Directorate of Health been given the task of assisting the hospitals in this work.

Through our work in the health care hospitals there has been voiced a need for systematization of the rules regarding a better application for the target groups children and adolescents in the specialist health service.

With this background RTVS initiated the establishing a professional network in which all hospitals were invited to participate. The participants jointly have a broad and solid competence as to research and clinical practice and have through their joint effort represented hospitalized as well as out patient perspectives.

The network has met three times during 2011, and in addition parts of the work has been done locally and in subgroups. Main themes of the work have been: age related adaption, network, mapping, evaluation and documentation.

RTVS and the working group suggest that the hospitals individually use this document as a foundation for their own procedures/guidelines. The document intends to enhance the quality Suicide prevention efforts for children and adolescents in the special health service.

\section{Nasjonale retningslinjer for forebygging av selvmord i psykisk helsevern ble publisert i 2008, og i tiden etterpå har det vært mye oppmerksomhet knyttet til implementering av disse i helsefore- takene. RVTS Øst og Sør har gjennom oppdragsbrev fra Helse- direktoratet fått i oppgave å bistå foretakene i dette arbeidet.}

Målgruppen for de nasjonale retningslinjene er definert til å være psykisk helsevern innenfor spesialisthelsetjenesten, de omhandler alle og det er ikke formulert inn særskilte alderstilpasninger. Gjennom vårt arbeid ute i foretakene/ sykehusene har det fra flere blitt fremhevet et behov for operasjonalisering av de nasjonale retningslinjene slik at de blir bedre tilpasset målgruppen barn og unge i spesialisthelsetjenesten.

Med bakgrunn i dette tok RVTS $\varnothing_{\text {st }}$ initiativ til etablering av et faglig nettverk der alle foretakene/sykehusene ble invitert til å delta med det formål å operasjonalisere/tilpasse de nasjonale retningslinjene til målgruppen barn/unge som kommer i kontakt med spesialisthelsetjenesten i psykisk helsevern. Deltakerne har til sammen representert bred og solid kompetanse forskningsmessig og klinisk, og har gjennom sin forankring representert både $\mathrm{d} \varnothing$ gnbehandling og det polikliniske perspektiv.

Nettverket møttes tre ganger i løpet av 2011 i tillegg til at arbeidet foregikk lokalt, og i undergrupper. Sentrale tema i arbeidet har vært: alderstilpasning, nettverk, kartlegging, vurdering og dokumentasjon.

Fra RVTS og arbeidsgruppen foreslås det at man ved de enkelte helseforetak anvender dette dokumentet som grunnlag for egne prosedyrer/retningslinjer. Dokumentet har til hensikt å øke kvaliteten i det selvmordsforebyggende arbeidet for barn og ungdom i spesialisthelsetjenesten.

\section{Familie og nettverks- perspektivet}

Foreldre med gode omsorgsferdigheter og et st $\varnothing t t e n d e$ nettverk er viktige beskyttelsesfaktorer når det gjelder å forebygge selvmord. Dersom barnet/ungdommen har en følelse av å være til byrde for familien og/eller kommunikasjonen og samhandlingen er vanskelig, kan dette være en risikofaktor. Det er viktig å styrke tilknytningen til omsorgspersonene.

En krise, som alvorlige selvmordsplaner/ -fors $\varnothing \mathrm{k}$ er, ber $\varnothing$ rer alle medlemmene i bør derfor tilbys hjelp. Krisen kan gi en mulighet til å oppdage noe nytt om relasjonene i familien og eventuelt få hjelp til å endre dem. Det kan være vanskelig å få en helhetlig forståelse av relasjonene ved bare å snakke med barnet/ungdommen. Det anbefales derfor at foreldrene/ andre omsorgspersoner deltar under hele eller deler av vurderingssamtalen. I den videre oppfølgingen og behandlingen bør man vektlegge både fysisk og psykologisk sikring. Foreldrenes/omsorgspersonenes rolle og delaktighet er viktig. Ved behov for innleggelse bør en oppfordre foreldrene/omsorgspersonene til å være til stede under oppholdet, noe som er en rettighet, jfr Pasientrettighetsloven $\S 6.2$ og Forskrift om barns opphold i helseinstitusjon. Dette må vurderes opp mot barnets/ungdommens alder og problemstilling.

Når barnevernet har omsorgen for barnet/ungdommen i foreldrenes sted, er det nødvendig at de som har den daglige omsorgen blir trukket inn i samarbeidet rundt barnet. Det anbefales å utarbeide lokale samarbeidsavtaler mellom barnevern og psykisk helsevern for barn og unge, slik at Lov om barneverntjenester og Lov om psykisk helsevern kan komplettere hverandre.

Foreldre/omsorgspersoner skal ha informasjon som er nødvendig for å oppfylle foreldreansvaret. De skal derfor ha informasjon når det foreligger selvmordsfare og pasienten er under 18 år. Dette fremgår av Pasientrettighetsloven $\S 3-4$. en familie og både foreldre og søsken 


\section{Kartlegging av selvmordsfare}

I "Nasjonale retningslinjer for forebygging av selvmord i psykisk helsevern" er det anført at alle pasienter i psykisk helsevern bør spørres om de har/har hatt selvmordtanker eller selvmordsplaner, og om de noen gang har gjort selvmordsfors $\varnothing \mathrm{k}$. Selvmord blant barn under 10 år er sjelden, og yngre barn har begrenset forståelse av hva selvmord innebærer. Samtidig vet vi at selvmordsproblematikk også forekommer blant de yngste. Det anbefales at eldre barn og ungdom spørres direkte om selvmordsatferd. Når det gjelder barn under 10 år innhentes først informasjon fra foreldre/omsorgspersoner. På bakgrunn av disse opplysningene vurderes det om barnet skal spørres direkte.

Når gravide henvises til psykisk helsevern for barn og unge før fødsel, gjøres kartlegging av selvmordsfare. Ved mulig selvmordsfare henvises pasienten videre.

Dersom det framkommer opplysninger om selvmordstanker eller planer, gjøres en vurdering av selvmordsfare.

\section{Vurdering av selvmordsfare}

Selvmordsfarevurdering skal gjøres av fagpersoner med nødvendig kompetanse (Se Nasjonale retningslinjer for forebygging av selvmord i psykisk helsevern). Foreldre/omsorgspersoner bør delta under samtalen, men barnet/ungdommen b $\varnothing \mathrm{r}$ gis anledning til å snakke uten foreldre/ omsorgspersoner tilstede.

Vurderingen tar utgangspunkt i barnet/ ungdommens egen opplevelse av situasjonen, og bygger på kunnskap om risiko og beskyttelsesfaktorer som nevnt nedenfor.

\section{Aktuelle tema:}

\section{Aktuell sykehistorie:}

Den siste tids hendelser og foranledning til vurderingssamtalen må kartlegges og dokumenteres. Det er viktig å la barnet/ ungdommen selv fortelle. Av særskilt interesse er det å få frem barnet/ungdommens hensikt med sine handlinger/tanker.

2. Utforsk selvmordstanker, planer og planlagt metode.

\section{Avdekking av risikofaktorer:}

- Statistiske bakgrunnsfaktorer: Psykisk lidelse, rusmiddelavhengighet/ rusmiddelmisbruk, tidligere selvmordsfors $\varnothing \mathrm{k}$, brudd i relasjoner, selvmord i familien/omgangskrets, mobbing, alvorlig selvskading, manglende nettverk, omsorgssvikt, seksuelle overgrep, fysisk og psykisk vold.

- Endringsfølsomme faktorer: Følelse av å være en byrde for familien/andre, opplevelse av tap, lav selvaktelse og mobbing (vær spesielt obs på sosiale medier), brudd og vansker i relasjoner, impulsivitet, håpløshet, hallusinasjoner, agitasjon og selvhat.

\section{Omsorgssituasjon/familie/nettverk:}

Barnet/ungdommens bosituasjon, kommunikasjon og samarbeid mellom foreldrene/omsorgspersoner, ressurser, foreldrenes psykiske helse, relasjonskonflikter. Andre familiemedlemmers eventuelle opplevelse av håpløshet/mangel på mening.

\begin{tabular}{|l|l|}
\hline Alder & Anbefalinger \\
\hline Under 6 år & $\begin{array}{l}\text { Dersom opplysninger fra foreldre/omsorgspersoner indikerer at barnet } \\
\text { har/har hatt tanker om å dø, ta livet sitt og/eller ikke ønsker å leve, } \\
\text { gjøres kartlegging direkte med barnet. }\end{array}$ \\
\hline $\begin{array}{l}\text { Foreldre/omsorgspersoner spørres om barnet har kommet med utsagn } \\
\text { ot.o.m. }\end{array}$ & $\begin{array}{l}\text { om å dø eller ta livet sitt og/eller om barnet har gjort selvmordsfors } ø \mathrm{k} . \\
\text { Dersom foreldrene/omsorgspersonene svarer ja på dette innkalles } \\
\text { barnet til samtale for å avklare om det foreligger selvmordstanker/- } \\
\text { planer. }\end{array}$ \\
\hline 10 år og & $\begin{array}{l}\text { Barnet/ungdommen spørres om de har, har hatt selvmordstanker eller } \\
\text { planer, og om de har gjort selvmordforsøk. }\end{array}$ \\
\hline eldre & \\
\hline
\end{tabular}

\section{Beskyttelsesfaktorer:}

Barnet/ungdommens mestringsressurser/ strategier, foreldre /omsorgspersoner med gode omsorgsferdigheter, st $\varnothing$ ttende nettverk/venner, fysisk og psykologisk sikkert milj $\varnothing$, meningsfylte aktiviteter for barnet/ungdommen og familien.

\section{Psykisk status presens:}

Aktuelle psykiske fungering; realitetsorientering, kontaktevne, kognitive fungering, psykomotorisk aktivitetsnivå, stemningsleie, tanke- og persepsjonsforstyrrelser m.m.

\section{Klinisk vurdering:}

Samlet klinisk vurdering baseres på punktene ovenfor, og skal konkludere med en gradering av aktuell selvmordsfare (ikke-avdekket, avdekket, overhengende), nødvendige tiltak, og når neste vurdering/oppfølging finner sted. Vurderingen skal journalføres uten opphold.

\section{Tiltak}

1. Ingen: I praksis vil dette sjelden være tilfellet med barn og unge som har vært til vurdering i forhold til selvmordsfare.

2. Poliklinisk oppfølging: Dette forutsetter at omsorgspersonene ivaretar pasienten, og vet hva de skal gjøre dersom situasjonen endrer seg og de vurderer selvmordsfaren $\varnothing \mathrm{kt}$. (Gi dem telefonnummer til Bup-klinikk, legevakt etc.) Snakk med barnet/ungdommen om hva de selv konkret kan gjøre dersom selvmordsimpulsene blir sterke, for eksempel ta i bruk egne mestringsstrategier de har erfaring med at hjelper, hvem de kan ta kontakt med etc. Konkret avtale neste kontakt og angi pasientens og de foresattes deltagelse/forståelse av situasjonen og avtalene.

\section{Ambulant oppf $\phi$ lging:}

Tett oppfølging av barnet/ungdommen i omsorgsbasen. Dette organiseres etter lokale forhold og avtaler.

4. Innleggelse i d $\phi$ gnavdeling: Dette kan være alternativet ved akutt selvmordsfare. (Husk nødvendige formaliteter.) Vurder behov for kontinuerlig- eller intervall-observasjon. 


\section{Avklare behov for eventuelle andre hjelpetiltak.}

Det må være samsvar mellom vurderingens konklusjon og tiltaket!

\section{Avslutning}

Oppfølging av arbeidet med implementering av de nasjonale retningslinjene for forebygging av selvmord vil fortsatt ha høy prioritet fra RVTS Øst sin side. Intensjonen med etableringen av arbeidsgruppen var å $\varnothing$ ke kvaliteten på det selvmordsforebyggende arbeidet for barn og ungdom i spesialisthelsetjenesten, giennom en operasjonalisering av de foreliggende nasjonale retningslinjer. Denne veilederen er ment som en bistand til helseforetakene/sykehusene, og som et utgangspunkt for lokale prosedyrer.

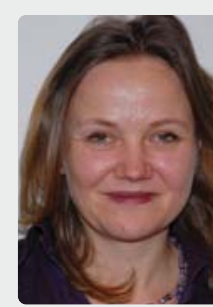

Kristin $\emptyset_{\text {stlie }}$ psykologspesialist Lovisenberg Diakonale sykehus/spesialrådgiver Regionalt ressurssenter om vold, traumatisk stress og selvmordsforebygging RVTS $\varnothing_{s t}$

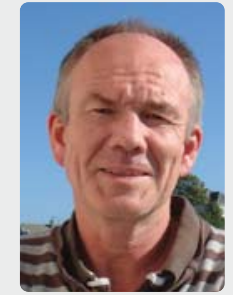

Nils Petter Reinholdt, fagteamleder, Regionalt ressurssenter om vold, traumatisk stress og selvmordsforebygging, RVTS Øst

\section{Arbeidsgruppens sammensetning}

Mona E. Bors Birkelund

Psykologspesialist,

BUP Øvre Romerike

Akershus Universitetssykehus

Anne Freuchen

Overlege, forsker

Sørlandet Sykehus HF

Anne-Lill Haddeland

Teamleder selvmordsforebygging

RVTS Sør

Ingebjørg Hestetun

Psykologspesialist, BUP Skien

Sykehuset Telemark HF

Johan Lindmark

Spesialrådgiver

RVTS Øst

Nils Petter Reinholdt

Teamleder selvmordsforebygging

RVTS Øst

Truls Fagernes Olsen

Psykologspesialst BUP,

Sykehuset i Vestfold HF
Hanne Nordheim Reitan

Overlege BUP Fredrikstad, Sykehuset Østfold HF

Liv Ristvedt

Seksjonsleder BUPA ungdomsenhet

- seksjon for øyeblikkelig hjelp, Vestre Viken HF

Gunnhild Winther Skogli

Psykolog BUP Lillehammer,

Sykehuset Innlandet HF

RVTS Nord

Johan Siqveland, Psykologspesialist

Akershus universitetssykehus HF

Gunnar Standal

Konst. psykologspesialist

BUP Lillehammer,

Sykehuset Innlandet HF

RVTS Midt

Line Stänicke

Psykologspesialist,

Nic Waals institutt

Lovisenberg Diakonale Sykehus

Kristin Østlie

Psykologspesialist

Lovisenberg Diakonale Sykehus/

RVTS Øst

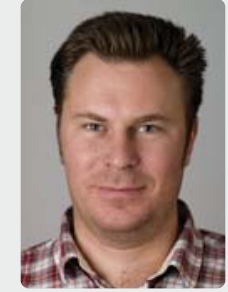

Johan Lindmark, spesialrådgiver, Regionalt ressurssenter om vold, traumatisk stress og selvmordsforebygging RVTS Øst

Referanser

Jobes, D.A. (2006). Managing suicidal risk. A colloraborative approach. London: Guilford Press. Joiner, T. (2005). Why people die by suicide. Boston: Harvard University Press.

Larsen, K. (2009). Sjekklister og skalaer ved vurdering av selvmordsrisiko. RVTS- $\varnothing_{\text {st }}$ [Online].

Sosial- og helsedirektoratet (2008). Nasjonale retningslinjer for forebygging av selvmord $\mathrm{i}$ psykisk helsevern. (IS-1511/2008) Oslo: Sosialog helsedirektoratet. 